\title{
Ekspresi Protein Resuscitation promoting factor-D Mycobacterium tuberculosis pada sel CHO-K1 secara in-vitro
}

\author{
Wahyu Agung Pratama ${ }^{1}$, Andriansjah Rukmana ${ }^{2}$, Fithriyah Sjatha ${ }^{2 *}$ \\ ${ }^{1}$ Program Magister Ilmu Biomedik, Fakultas Kedokteran, Universitas Indonesia; \\ Jl. Salemba 4 Jakarta 10320, Indonesia. \\ ${ }^{2}$ Departemen Mikrobiologi, Fakultas Kedokteran, Universitas Indonesia, \\ Jl. Pegangsaan Timur 16, Cikini, Jakarta 10320, Indonesia. \\ *E-mail: titisjatha@yahoo.com
}

\begin{abstract}
Abstrak
Protein Resuscitation promoting factor-D (Rpf-D) merupakan protein transmembran dari Mycobacterium tuberculosis dan dieskpresikan pada fase reaktivasi infeksi laten menjadi aktif. Protein Rpf-D tersusun atas 154 asam amino berukuran $16 \mathrm{kDa}$ yang dikode oleh 456 basa dari famili gen-Rpf. Pada studi sebelumnya, kami telah berhasil mengklona gen rpfD dari Mycobacterium tuberculosis strain Beijing kedalam plasmid pcDNA3.1, dikenal sebagai pcDNA3.1-rpfD. Dalam studi ini, kami mentransfeksi sel mamalia CHO-K1 dengan plasmid rekombinan pcDNA3.1-rpfD dan dilanjutkan dengan pewarnaan imunologis menggunakan serum mencit yang telah diimunisasi dengan pcDNA3.1-rpfD sebagai vaksin DNA. Hasil pewarnaan menunjukkan bahwa protein RpfD mampu diekspresikan pada sel mamalia. Selain itu, protein rekombinan yang diekspresikan ini terbukti bersifat imunogenik dan mampu menginduksi respon imun humoral pada hewan uji mencit $\mathrm{Balb} / \mathrm{C}$ berupa IgG1, IgG2a, IgG2b dan IgG3. Hasil penelitian ini menunjukan potensi pemanfaatan protein rekombinan $\mathrm{RpfD}$ untuk penelitian lanjutan pengembangan vaksin ataupun uji diagnosis tuberkulosis.
\end{abstract}

Kata kunci: Resuscitation promoting factor-D, Mycobacterium tuberculosis, sel CHO-K1, transfeksi, immunostaining

\begin{abstract}
Resuscitation promoting factor-D (Rpf-D) protein is known as a component of Mycobacterium tuberculosis cell wall which highly expressed in reactivation state of latent tuberculosis to turn in to an active infection. Rpf-D protein is a small protein consist of 154 amino acids encoded by 465 nucleotides in Rpf-gene family and having $16 \mathrm{kDa}$ in size. In our previous study, we had successfully cloned Rpf-D gene of Mycobacterium tuberculosis Beijing strain into pcDNA3.1 plasmid expression system, which named as pcDNA3.1-rpfD later on. In this study, we transfect pcDNA3.1-rpfD into CHO-K1 mammalian cell line followed by immunostaining using mice sera immunized with pcDNA3.1-rpfD as DNA vaccine. Our result shows that our recombinant pcDNA3.1-rpfD construct can express recombinant RpfD protein in mammalian cells. On the other hand, this expressed recombinant protein has been proven to be immunogenic and able to induce a humoral immune response in Balb/C mice especially IgG1, IgG2a, IgG2b, and IgG3. Our study has shown the potency of recombinant RpfD protein which can be further developed as vaccine or diagnostic approach for tuberculosis.
\end{abstract}

Keywords: Resuscitation promoting factor-D, Mycobacterium tuberculosis, CHO-K1 cells, transfection, immunostaining

\section{Pendahuluan}

Tuberkulosis (TB) merupakan penyakit infeksi yang disebabkan oleh kuman Mycobacterium tuberculosis. ${ }^{1}$ WHO memperkirakan lebih dari sepertiga populasi di dunia terinfeksi oleh kuman ini 
dengan angka kematian mencapai 1,3 juta orang per tahunnya. ${ }^{2}$ Manifestasi TB pada manusia dapat berupa infeksi aktif dan infeksi laten yang dibedakan melalui ada tidaknya gejala infeksi. Penderita infeksi laten diperkirakan terjadi pada 9 juta orang diseluruh dunia. ${ }^{3}$ Infeksi laten ini kemudian dapat menjadi infeksi aktif saat imunitas inang menurun. ${ }^{4}$

Pengobatan TB dapat dilakukan melalui administrasi Obat Anti Tuberkulosis (OAT) secara multi obat. Namun kini, banyak ditemukan kasus resistensi OAT yang menyebabkan infeksi TB sulit ditangani. ${ }^{5}$ Selain dengan OAT, salah satu cara terbaik dalam mencegah kasus TB adalah melalui vaksinasi. Satusatunya vaksin yang tersedia untuk TB adalah vaksin Bacille Calmette Guérin (BCG) yang telah digunakan secara luas diseluruh dunia ${ }^{6}$, namun diketahui vaksin ini tidak memberikan tingkat proteksi yang sama pada semua kelompok usia ${ }^{7}$ dan tidak dapat melindungi reaktivasi infeksi laten menjadi infeksi aktif TB, sehingga banyak penelitian kini difokuskan dalam mengembangkan vaksin TB alternatif.

Protein Resuscitation promoting factor-D (Rpf-D) merupakan protein dinding sel $M$. tuberculosis yang diekspresikan saat $M$. tuberculosis tereaktivasi dari laten menjadi aktif. $^{7}$ Protein Rpf-D termasuk dalam keluarga protein Rpf. Protein ini memiliki ukuran $16 \mathrm{kDa}$ yang tersusun atas 154 asam amino dan dikode oleh 456 basa. Menurut literatur, protein Rpf-D dalam jumlah kecil mampu menstimulasi pertumbuhan bakteri dan berperan sebagai faktor pertumbuhan. ${ }^{7}$

Beberapa penelitian telah mengembangkan protein rekombinan RpfD menggunakan berbagai sistem ekspresi. ${ }^{7}$ Berdasarkan penelitian tersebut dapat disimpulkan bahwa protein Rpf-D terbukti bersifat imunogenik secara in-vivo. ${ }^{7}$ Pada penelitian ini, dilakukan pengujian ada tidaknya ekspresi protein Rpf-D rekombinan dari plasmid pcDNA3.1-rpfD yang telah dikonstruksi sebelumnya ${ }^{8}$
(Gambar 1) pada sistem ekspresi sel mamalia menggunakan galur sel CHO-K1. Sel ini memiliki karakter mudah ditumbuhkan dalam media kultur minimal dan memiliki kemampuan untuk mengekspresikan protein rekombinan dengan modifikasi pasca translasi yang baik jika dibandingkan dengan sel nonmamalia. ${ }^{9}$ Penelitian ini akan memberikan data awal untuk pengembangan vaksin atau uji imunodiagnostik tuberkulosis berbasis DNA (pcDNA3.1-rpfD) dimasa depan.

\section{Metode}

\section{Galur Sel mamalia}

Galur sel mamalia CHO-K1 (Kobe University, 2011) digunakan sebagai sel mamalia pengekspresi protein RpfD rekombinan. Sel CHO-K1 ditumbuhkan dalam medium Minimal Essential Media (MEM, Sigma) yang mengandung 10\% Fetal Bovine Serum (FBS, Gibco), 1\% Non-essential amino acid (NEAA, Sigma) dan $1 \%$ antibiotik - antimikotik (Sigma). Kultur sel CHO-K1 dilakukan dalam kondisi temperatur $37^{\circ} \mathrm{C}$ dan $5 \% \mathrm{CO}_{2}$ dan pasase sel dilakukan saat sel mencapai $100 \%$ konfluensi $\left(1 \times 10^{5} \mathrm{sel} / \mathrm{mL}\right)$ dengan penambahan tripsin (Sigma).

\section{Plasmid rekombinan pcDNA3.1-rpfD}

Plasmid rekombinan telah dikonstruksi oleh penelitian sebelumnya ${ }^{8}$ (Gambar 1). Untuk perbanyakan plasmid, sel E.coli DH5a digunakan sebagai host plasmid rekombinan pembawa pcDNA3.1rpfD dan plasmid pcDNA3.1 wild type (wt) yang dikultur dalam media Luria Bertani (Sigma) mengandung $100 \mu \mathrm{g} / \mathrm{mL}$ antibiotik ampisilin (Sigma) dengan kondisi aerob dengan agitasi $200 \mathrm{rpm}$ pada suhu $37{ }^{\circ} \mathrm{C}$ selama 18 jam. Plasmid rekombinan kemudian diisolasi menggunakan HiSpeed Plasmid Midi Kit Qiagen dan PureLink ${ }^{\circledR}$ HiPure Plasmid Filter Purification Kits (Midi Preparation Kits) sesuai prosedur manufaktur. Plasmid hasil isolasi kemudian dianalisis 
integrasinya menggunakan elektroforesis gel agarose disertai visualisasi dengan UV serta konsentrasi dan kemurniannya menggunakan analisis spektrofotometri (NanoDrop 2000, BioTek).

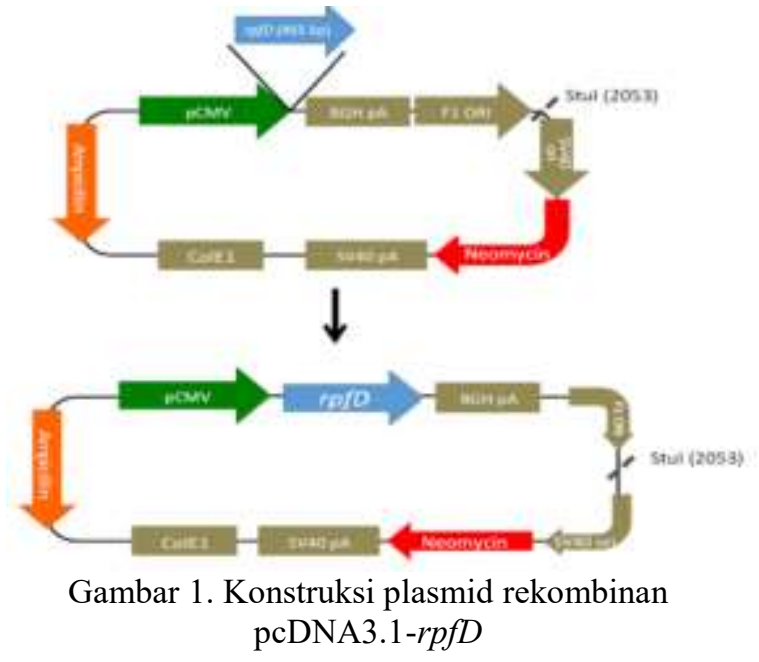

\section{Produksi antibodi mencit anti-RpfD}

Empat belas ekor mencit Balb/c jantan (mencit inbreeding diperoleh dari PT Indo Anilab Bogor dan Fakultas Peternakan Institusi Pertanian Bogor) usia 6 minggu diimunisasi dengan plasmid rekombinan pcDNA3.1-rpfD dan pcDNA3.1 (wt) (masing-masing 7 ekor mencit per kelompok) dengan dosis 100 $\mu \mathrm{g}$ plasmid dalam $100 \mu \mathrm{L}$ dapar TrisEDTA tanpa adjuvant per kali imunisasi secara intramuskular di otot quadriceps femoral menggunakan syringe. Imunisasi dilakukan sebanyak 3 kali dengan interval waktu 1 minggu. Darah mencit sebanyak $200 \mu \mathrm{L}$ dikoleksi secara retroorbital sesaat sebelum imunisasi. Dua minggu setelah imunisasi terakhir, mencit di eutanasia dan darah dikoleksi melalui pengambilan intra kardiak. Sampel darah yang telah dikumpulkan kemudian disentrifugasi pada kecepatan 3.000 rpm selama 5 menit pada temperatur ruang. Serum diambil dan disimpan pada suhu $-30^{\circ} \mathrm{C}$ untuk penggunaan berikutnya. Penggunaan hewan coba dalam penelitian ini telah disetujui oleh Komite Etik Penelitian FKUI-RSCM dengan No. ND313/UN2.F1/ETIK/PPM.00.02/2019.

\section{Antibodi primer dan sekunder}

Pada penelitian ini, pewarnaan sel dianalisis secara imunologi menggunakan dua jenis serum, yaitu serum mencit terminasi dan serum pasien terkonfirmasi infeksi Flavivirus (koleksi Laboratorium Mikrobiologi FKUI), serum ini merupakan antibodi primer. Sebagai antibodi sekunder digunakan Goat-anti mice/human IgG berlabel enzim horseradish peroxidase (HRP, Sigma, untuk identifikasi respon humoral IgG total) dan Goat-anti mice

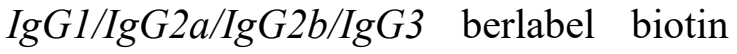
(BioLegend).

\section{Transfeksi sel CHO-K1}

Transfeksi sel CHO-K1 dilakukan pada plat kultur yang memiliki 24 sumur. Kultur sel dengan kepadatan $1 \times 10^{5} \mathrm{sel} / \mathrm{mL}$ ditransfeksi dengan plasmid pcDNA3.1 sebagai kontrol dan pcDNA3.1-rpfD (perlakuan) sebanyak $8 \mu \mathrm{g}$ menggunakan reagen Lipofectamine ${ }^{\circledR}$ LTX \& Plus Reagent (Invitrogen) dengan tahapan sesuai petunjuk manufaktur. Dalam tahapan ini, plasmid rekombinan pcJEME (plasmid pcDNA3.1 rekombinan pembawa gen selubung virus Japanese encephalitis; koleksi Laboratorium Mikrobiologi FKUI) disertakan sebagai kontrol positif transfeksi dan pewarnaan imunologi.

\section{Deteksi ekspresi protein Rpf-D rekombinan pada sel CHO-K1}

Dua puluh empat jam pasca transfeksi, sel CHO-K1 dicuci menggunakan Phosphate Buffer Saline (PBS) 1X dan difiksasi menggunakan etanol absolut dingin dan diinkubasi selama selama 30 menit pada suhu $4^{\circ} \mathrm{C}$. Larutan antibodi primer berupa serum mencit terminasi (1:100) atau serum pasien (1:500) terkonfirmasi infeksi Flavivirus sebagai kontrol positif, yang telah didilusi didalam PBS ditambahkan kedalam sel CHO-K1 yang telah difiksasi. Sel dan antibodi kemudian diinkubasi selama 1 jam pada suhu ruang. Setelah inkubasi, sel kemudian dicuci dengan PBS, dilanjutkan 
dengan penambahan antibodi sekunder berupa Goat-anti mice IgG-HRP (Sigma) atau Goat-anti human IgG-HRP (Sigma) untuk sumuran kontrol dengan dilusi 1:5000 dalam dapar PBS 1X dan dilanjutkan dengan inkubasi selama 1 jam. Usai inkubasi, sel dicuci kembali dengan PBS 1X dan ditambahkan substrat diamino benzidine (DAB, Sigma). Sel kemudian diamati dibawah mikroskop inverted dengan perbesaran 400x. Sel dengan ekspresi antigen positif akan memberi warna lembayung.

\section{Deteksi sub-kelas IgG mencit}

Sub kelas IgG dalam serum mencit dideteksi menggunakan metode pewarnaan imunologis seperti tahapan diatas, dengan antibodi sekunder berupa 1:5000 Goat-anti mice IgG1/IgG2a/IgG2b/IgG3 berlabel biotin (Biolegend) yang dilanjutkan dengan kompleks HRP-avidin (Abcam) selama 1 jam pada suhu ruang dan substrat DAB.

Hasil

\section{Deteksi ekspresi protein RpfD rekombinan}

Hasil pewarnaan imunologi terhadap sel CHO-K1 pasca transfeksi (Gambar 2) terlihat adanya sel berwarna lembayung, seperti yang ditunjukkan pada sel yang ditransfeksi dengan pcDNA3.1-rpfD (Gambar 2D) dan pcJEME (Gambar 2B) sebagai kontrol positif. Hasil ini mengindikasikan bahwa protein rekombinan Rpf-D terekspresi pada sel CHO-K1. Sementara, pada sel CHO-K1 yang ditransfeksi oleh plasmid wt pcDNA3.1 (kontrol), tidak terlihat warna lembayung.
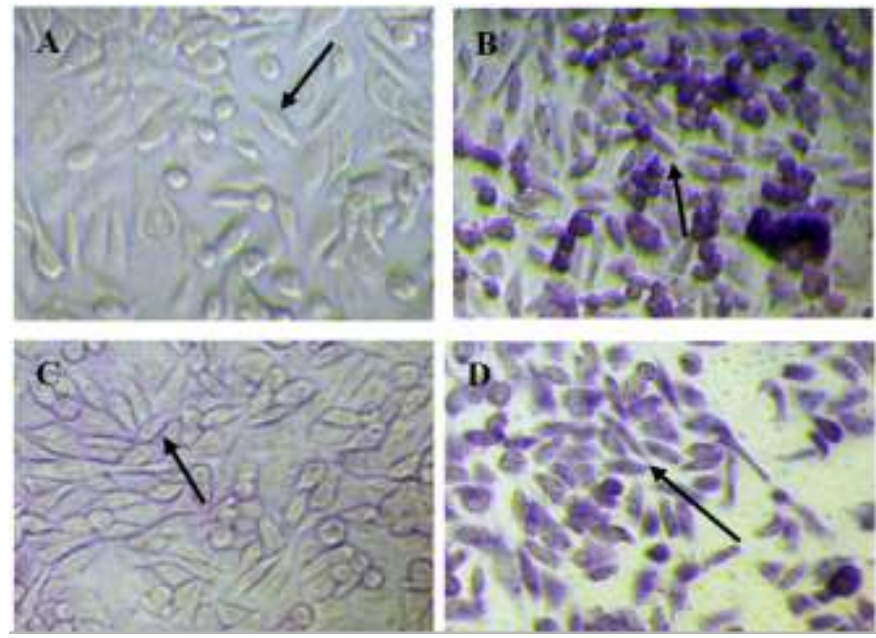

Gambar 2. Visualisasi sel CHO-K1 pasaca pewarnaan imunologis pada perbesaran 400x. Tanda panah menunjukan sel CHO-K1, A. Kontrol negatif (tanpa transfeksi), B. Kontrol positif (transfeksi dengan plasmid rekombinan pcJEME), C. Kelompok sel yang ditransfeksi dengan plasmid pcDNA3.1 (wt), D. Kelompok sel yang ditransfeksi dengan plasmid pcDNA3.1-rpfD.

\section{Deteksi sub-kelas IgG mencit}

Sub-kelas IgG mencit yang diimunisasi dengan plasmid rekombinan $p c D N A 3.1-r p f D$ dideteksi dengan pewarnaan imunologis sebagaimana terlihat pada gambar 3. Dari gambar tersebut, terlihat bahwa semua sub-kelas
$\operatorname{IgG}$ (IgG1， IgG2a， IgG2b, dan IgG3) mencit berhasil terinduksi dan bereaksi dengan protein Rpf-D rekombinan yang diekspresikan pada sel CHO-K1, ${ }^{10,11}$ ditandai dengan adanya sel yang terwarnai lembayung (Gambar 2A - D) sementara pada kontrol negatif (Gambar 1A - D) tidak terlihat warna lembayung. ${ }^{12,13}$ 


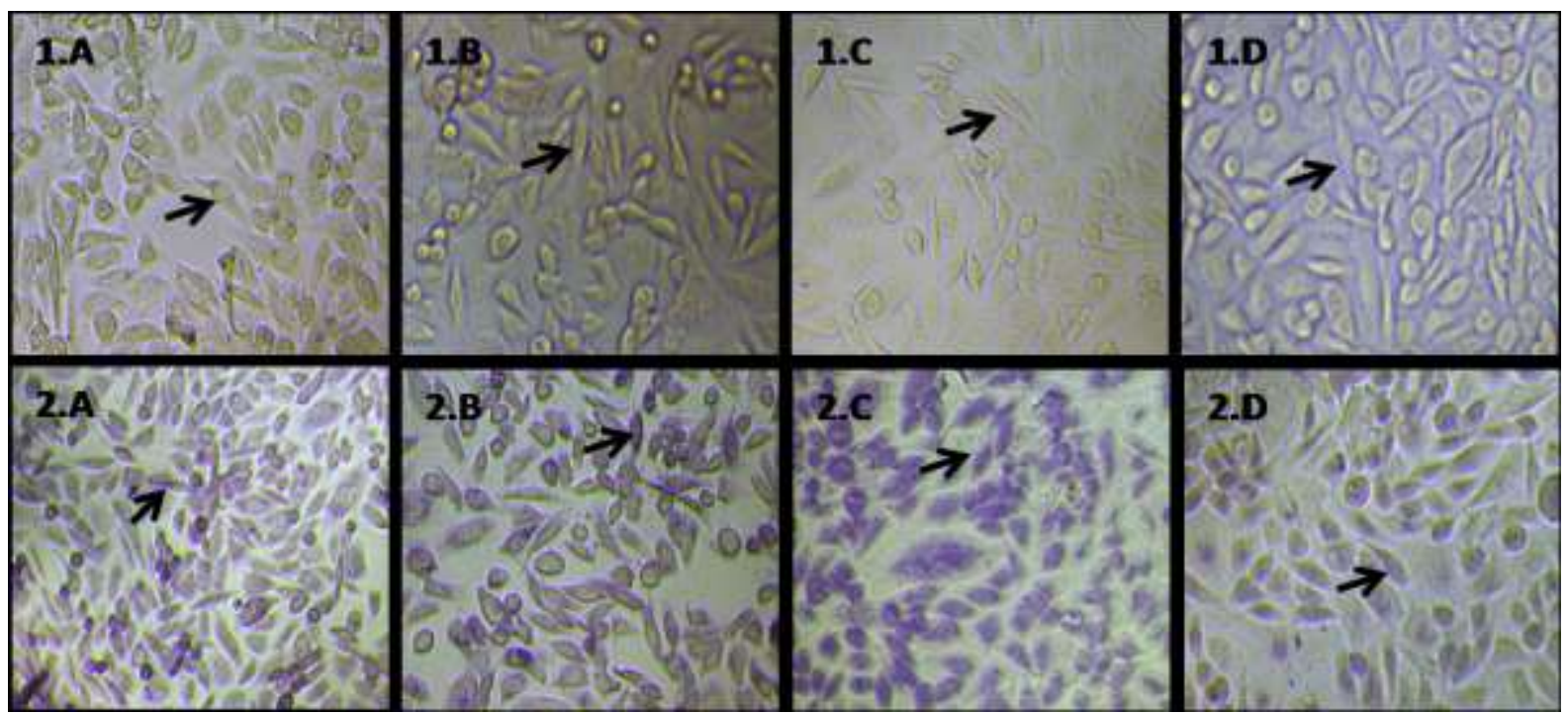

Gambar 3. Visualisasi sel CHO-K1 pasca pewarnaan imunologi

Keterangan : Kelompok 1: sel CHO-K1 yang ditransfeksi dengan pcDNA3.1;

Kelompok 2 : sel CHO-K1 yang ditransfeksi dengan pcDNA3.1-rpfD. Kedua

kelompok diwarnai dengan antibodi primer serum mencit terminasi dan antibodi sekunder anti mencit: A.IgG1; B. IgG2a; C. IgG2b; dan D. IgG3 (perbesaran 400x).

\section{Pembahasan}

TB merupakan penyakit infeksi nomor satu didunia. Infeksi ini menjadi permasalahan yang serius secara global dimana upaya eradikasi penyakit haruslah berjalan dengan multi faktor, mulai dari pencegahan melalui vaksinasi ${ }^{14}$, diagnosis yang tepat dan pengobatan yang sesuai. Beberapa tantangan dalam eradikasi TB diantaranya dalam hal diagnosis TB laten dan vaksin $\mathrm{BCG}$ yang menunjukan efikasi yang sangat bervariasi dalam memberikan perlindungan terhadap penyakit $\mathrm{TB}^{4}$ Infeksi laten TB pada pasien umumnya tidak bergejala ataupun memberikan manifestasi bermakna klinis sehingga dapat memperlambat administrasi OAT pada penderita. ${ }^{4}$ Selain itu, BCG sebagai satu satunya vaksin TB yang ada, terbukti tidak memberikan tingkat proteksi yang sama pada seluruh populasi dan tidak mampu mencegah reaktivasi infeksi TB laten menjadi aktif. ${ }^{4}$ Hal ini mendorong dilakukannya berbagai upaya untuk mengembangkan diagnosis infeksi TB laten dan vaksin TB alternatif selain vaksin BCG.

Dalam penelitian ini, telah
dikembangkan plasmid rekombinan
pcDNA3.1-rpfD yang terbukti mampu
mengekspresikan protein RpfD
rekombinan pada sel mamalia CHO-K1.
Pemilihan protein RpfD sebagai protein
rekombinan didasari data bahwa protein
ini merupakan protein yang terdapat pada
bakteri $M$. tuberculosis dan berperan saat
terjadi reaktivasi TB laten menjadi TB
aktif, selain itu berdasarkan hasil
penelitian sebelumnya, protein ini terbukti
memiliki kemampuan antigenisitas dan
bersifat imunogenik. ${ }^{7}$ Dari hasil analisis
in-silico diketahui protein Rpf-D memiliki
beberapa epitop dengan afinitas kuat yang
dapat dikenali oleh sel B dalam
menginduksi respon imun humoral (data
tidak ditampilkan). Selain itu, secara
struktural, protein Rpf-D memiliki
beberapa domain yang terpapar ke
lingkungan sehingga meningkatkan
kemungkinannya untuk dikenali sistem
imun. Konstruksi plasmid pcDNA3.1-rpfD
pada studi ini berbeda dengan studi yang
ada sebelumnya, dimana sumber gen rpfD
yang digunakan berasal dari $M$.


tuberculosis strain Beijing yang memiliki sirkulasi lebih besar di Indonesia. Selain itu, plasmid pembawa yang digunakan adalah pcDNA3.1 yang telah umum digunakan dalam studi ekspresi protein rekombinan pada sel mamalia dengan hasil yield protein terekspresi yang tinggi.

$\begin{array}{ccc}\text { Pemilihan } & \text { sel inang } & \begin{array}{c}\text { dalam } \\ \text { mengekspresikan }\end{array} \\ \text { suatu } & \text { protein }\end{array}$
rekombinan merupakan hal yang sangat penting. Sel CHO-K1 yang digunakan dalam peneletian ini merupakan jenis sel yang biasa digunakan dalam produksi berbagai protein rekombinan, karena memiliki beberapa keunggulan, diantaranya selnya mudah untuk dipropagasi dan hanya memerlukan media tumbuh yang minimal. Selain itu, dengan menggunakan sistem ekspresi sel mamalia, diharapkan protein yang terbentuk merupakan protein yang sesuai bagi sel eukariot karena protein telah mengalami modifikasi pasca translasi, sehingga memiliki antigenisitas dan imunogenisitas yang lebih baik.

Penelitian ini juga menunjukkan bahwa plasmid rekombinan pcDNA3.1$r p f D$ yang telah dikonstruksi memiliki kemampuan menginduksi respon imun humoral pada hewan uji mencit. Respon humoral berupa terbentuknya Imunoglobulin-G (IgG) ini terdeteksi pada semua sub-kelas IgG dengan tingkat induksi yang bervariasi yang terlihat secara kualitatif dari jumlah dan intensitas warna dari sel yang terwarnai.

Pada penelitian ini kontrol positif berupa antigen RpfD rekombinan ataupun antibodi anti-RpfD tidak digunakan karena tidak tersedianya kedua reagensia tersebut secara komersial. Pewarnaan imunologis yang dilakukan membuktikan adanya ekspresi protein rekombinan RpfD oleh konstruksi plasmid pcDNA3.1-RpfD baik di kultur sel mamalia CHO-K1 maupun invivo pada mencit, yang dalam hal ini juga membuktikan imunogenisitas protein rekombinan yang diekspresi dalam menginduksi respon humoral mencit. Pada penelitian ini juga dilakukan imunisasi mencit hanya dengan pcDNA3.1 dengan asumsi akan diperoleh antibodi yang akan digunakan sebagai kontrol negatif pewarnaan yang memberikan hasil tidak ada sel yang terwarnai (data tidak ditunjukkan).

Penelitian selanjutnya dari hasil yang telah dicapai ini, dapat diarahkan pada uji konfirmasi bahwa protein rekombinan yang terbentuk dari injeksi plasmid rekombinan RpfD adalah benar-benar RpfD dengan Western Blot menggunakan antibodi komersial RpfD dan kuantifikasi kadar antibodi anti RpfD yang terbentuk maupun uji proteksi secara in-vivo ataupun in-vitro pcDNA.31-rpfD dalam infeksi $M$. tuberculosis.

\section{Kesimpulan}

Protein RpfD rekombinan telah berhasil diekspresikan oleh plasmid pcDNA3.1-rpfD pada sistem ekspresi sel CHO-K1. Protein rekombinan yang diekspresikan ini bersifat imunogenik dan mampu menginduksi respon imun humoral pada hewan uji mencit Balb/C. Respon imun humoral mencit yang diinduksi diantaranya: IgG1, IgG2a, IgG2b dan IgG3.

\section{Daftar Rujukan}

1. Nurwidya F, Handayani D, Burhan E, Yunus F. Molecular Diagnosis of Tuberculosis. Chonnam Med J. 2018;54(1):1.

2. Macneil A, Glaziou P, Sismanidis C, Maloney S, Floyd K. Global epidemiology of tuberculosis and progress toward achieving global targets - 2017. Morb Mortal Wkly Rep. 2019;68(11):263-6.

3. WHO. global TUBERCULOSIS Executive summary. Organ Mund la salud [Internet]. 2018;8. Available from: http://www.who.int/tb/publications/global_repo rt/tb18_ExecSum_web_4Oct18.pdf?ua $=1 \% 0 \mathrm{Ah}$ $\mathrm{ttp}: / / \mathrm{www}$. who.int/tb/publications/global_report /tb18_ExecSum_web_4Oct18.pdf

4. Seidi K, Jahanban-Esfahlan R. A novel approach to eradicate latent TB: Based on resuscitation promoting factors. $\mathrm{J}$ Med Hypotheses Ideas [Internet]. 2013;7(2):69-74. Available from: http://dx.doi.org/10.1016/j.jmhi.2013.04.002 
5. Brossier F, Guindo D, Pham A, Reibel F, Sougakoff W, Veziris N, et al. Test for Detection of Resistance to Second-Line Drugs in Multidrug- Resistant Mycobacterium tuberculosis Complex Strains. J Clin Microbiol. 2016;54(6):1573-80.

6. Moliva JI, Turner J, Torrelles JB. Immune responses to bacillus Calmette-Guérin vaccination: Why do they fail to protect against mycobacterium tuberculosis? Front Immunol. 2017;8(APR).

7. Romano M, Aryan E, Korf H, Bruffaerts N, Franken CLMC, Ottenhoff THM, et al. Potential of Mycobacterium tuberculosis resuscitation-promoting factors as antigens in novel tuberculosis sub-unit vaccines. Microbes Infect [Internet]. 2012;14(1):86-95. Available from:

http://dx.doi.org/10.1016/j.micinf.2011.08.011

8. Rakhmawati A, Rukmana A, Karuniawati A. Construction of pcDNA3.1 Vector Encoding rpfD Gene of Mycobacterium tuberculosis. Makara J Sci. 2018;22(3):149-54.

9. Hn IA, Pada VP, Sel K, Ovarian C, Cho H, Fadhilah FR, et al. Uji In Vitro Vaksin DNA Pengekspresi Antigen Fusi Hemaglutinin Virus Uji In Vitro Vaksin DNA Pengekspresi Antigen Fusi Hemaglutinin Virus Influenza A H5N1 dan
VP22 Pada Kultur Sel Chinese Ovarian Hamster ( CHO ). 2019; (August).

10. Goel MM, Budhwar P. Species-specific immunocytochemical localization of Mycobacterium tuberculosis complex in fine needle aspirates of tuberculous lymphadenitis using antibody to $38 \mathrm{kDa}$ immunodominant protein antigen. Acta Cytol. 2008;52(4):424-33.

11. Zhou S, Chen Y, Gong X, Jin J, Li H. Site-specific integration of light chain and heavy chain genes of antibody into CHO-K1 stable hot spot and detection of antibody and fusion protein expression level. Prep Biochem Biotechnol [Internet]. 2019;49(4):384-90. Available from: https://doi.org/10.1080/10826068.2019.157319 6

12. Kabiraj A, Gupta J, Khaitan T, Bhattacharya PT. Principle and Techniques of Immunohistochemistry - a Review. Int J Biol Med Res. 2015;6(3):5204-10.

13. Korsnes I, Mk E. Immunohistochemistry principles and methods. Diagnostic Clin Pathol. 2009;1-36.

14. Bruffaerts N, Huygen K, Romano $\mathrm{M}$. DNA vaccines against tuberculosis. Expert Opin Biol Ther. 2014;14(12):1801-13. 